\title{
Erysiphe biocellata, um Novo Patógeno de Mentha arvensis no Brasil
}

\author{
Edival A. V Zauza ${ }^{1}$, Acelino C. Alfenas ${ }^{1} \&$ Clarice N. L. Silva ${ }^{1}$ \\ ${ }^{1}$ Departamento de Fitopatologia, Universidade Federal de Viçosa, CEP 36571-000, Viçosa, MG, email: edival@ufv.br
}

(Aceito para publicação em 15/04/2003)

Autor para correspondência: Edival A Valverde Zauza

\section{ABSTRACT}

Erysiphe biocellata, a new pathogen of Mentha arvensis, in Brazil A severe attack of Erysiphe biocellata was observed in

O gênero Mentha abrange cerca de 25 espécies de hortelãs e pertence à família Labiatae. Mentha citrata Ehrb. (menta-do-levante), $M$. piperita L. (hortelã pimenta) e $M$. arvensis Linn. (menta japonesa) são as espécies mais populares, sendo esta última de grande importância econômica, pois dela se extrai um óleo essencial, o mentol, muito utilizado pela indústria farmacêutica, de higiene e de tabaco. Em uma inspeção de rotina realizada em área experimental da Universidade Federal de Viçosa, observaram-se plantas de M. arvensis subdesenvolvidas e com folhas recobertas por uma massa branca e pulverulenta (Figura 1A) de um fungo semelhante a espécies do gênero Oidium. Exames microscópicos mostraram que o fungo apresentava as seguintes características morfológicas: conidióforos de base reta e não-ramificada, célula basal cilíndrica, 30-55 $\mu \mathrm{m}$ x 10-15 $\mu \mathrm{m}$, conídios em cadeia de formato ovóide a doliforme, 25-42 x 14-24 $\mu \mathrm{m}$ e com germinação do tipo cichoracearum, típicos de Erysiphe biocellata Ehrenb. (Figura 1C e D) conforme descrito por Braun (1987). Plantas sadias de M. arvensis foram inoculadas mediante pincelamento de esporos e em seguidas mantidas em casa de vegetação com temperatura variando entre 21 a $25^{\circ} \mathrm{C}$. Plantas pinceladas com água serviram como controle. Após dez dias de inoculação, as folhas das plantas apresentavam-se recobertas por uma massa esbranquiçada de estruturas do fungo (Figura 1B). Este é o primeiro registro de E. biocellata causando míldio pulverulento em $M$. arvensis no Brasil. plantations of Mentha arvensis in Viçosa-MG on July 2002. This is the first time that this disease was detected in Brazil.

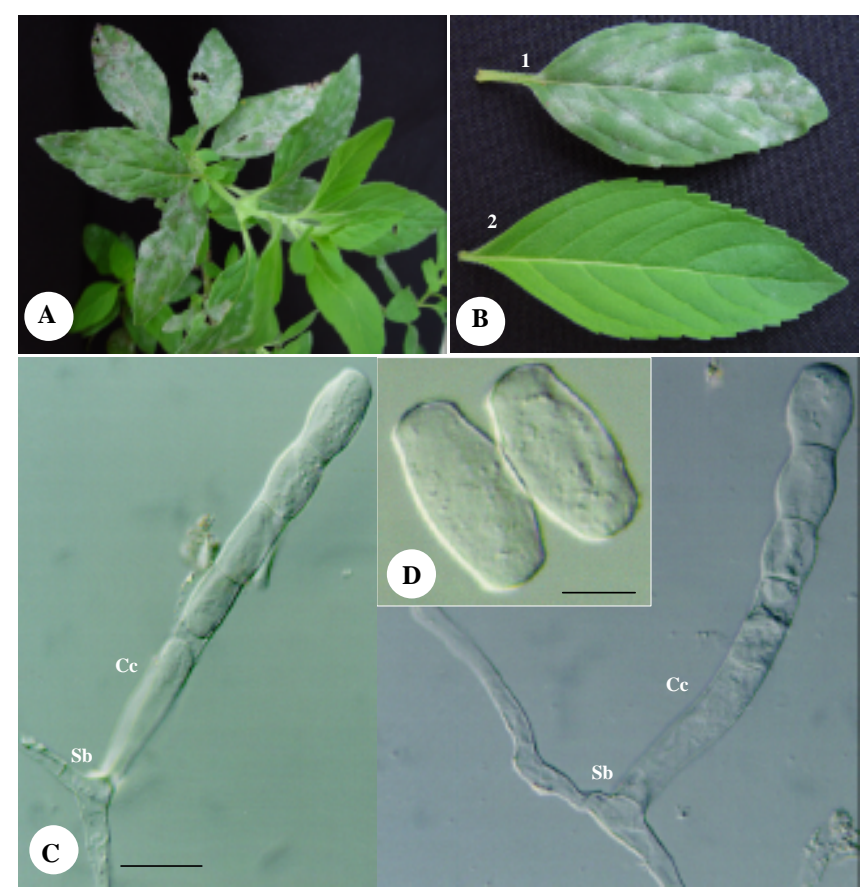

FIG. 1 - A - Planta de Mentha arvensis colonizada naturalmente por Erysiphe biocelatta; B - Detalhe de folha inoculada mediante pincelamento de estrutura fúngica (1) e pincelada com água (2), controle; C - Conidióforos e conídios do fungo observado o microscópio de luz, onde: $\mathrm{Sb}=$ septo basal e $\mathrm{Cc}=$ célula conidiogênica $($ barra $=10 \mu \mathrm{m})$; e D - Detalhe do conídio $($ barra $=5 \mu \mathrm{m})$ 